\title{
Simultaneous determination of nitrite, nitrate, sulphate and phenolic compounds, by sequential injection analysis, in wastewaters
}

\author{
R.A.S. Lapa*, J.L.F.C. Lima and I.V.O.S. Pinto \\ CEQUP/Departamento de Química-Física, Faculdade de Farmácia da Universidade do Porto, \\ R. Aníbal Cunha, 164-4050 Porto, Portugal
}

\begin{abstract}
A sequential injection analysis (SIA) system for the simultaneous determination of nitrite, nitrate, sulphate and phenolic compounds, in wastewaters has been developed. The nitrite determination is based on the Griess-Llosvay reaction. Nitrate is previously reduced to nitrite in a copperized cadmium column and analyzed as nitrite. The sulphate determination is based on the turbidimetric determination using barium chloride as reagent. The phenolic compounds determination is based on oxidative coupling with 4-aminoantipyrine (4-AAP) in alkaline solution. The resulting products of each reaction were spectrophotometrically measured at $540 \mathrm{~nm}$. The proposed system is fully automatized and is able to monitor nitrite, nitrate, sulphate and phenolic compounds, simultaneously, in samples at a frequency of about 12 samples per hour with a relative standard deviation (RSD) better than $2.0 \%, 0.7 \%, 1.5 \%$ and $2.2 \%$, respectively. The calibration graph is linear between 0.05 and $25 \mathrm{mg}^{-\mathrm{dm}^{-3}}$ for nitrite, 0.05 and $15 \mathrm{mg} \cdot \mathrm{dm}^{-3}$ for nitrate, 5 and $200 \mathrm{mg} \cdot \mathrm{dm}^{-3}$ for sulphate and, finally, between 0.5 and $25 \mathrm{mg} \cdot \mathrm{dm}^{-3}$ for phenolic compounds.
\end{abstract}

Keywords: Sequential injection analysis - nitrite - nitrate - sulphate - phenolic compounds - wastewaters.

\section{Introduction}

There is an increasing need of process analysers to monitor water chemical parameters such as nitrite, nitrate, phenolic compounds and sulphate in natural water streams and industrial effluents due to the widespread industrial use of sulphuric acid [1], the increased use of nitrogen-based fertilizers over the last years [2-4] and the extensively phenolic compounds use as pesticides, herbicides and fungicides [5]

The limits of emission values in the discharge of wastewaters, presented in the Portuguese Legislation [6] are $50 \mathrm{mg} \cdot \mathrm{dm}^{-3}$ for nitrate, $2000 \mathrm{mg} \cdot \mathrm{dm}^{-3}$ for sulphate and $0.5 \mathrm{mg} \cdot \mathrm{dm}^{-3}$ for phenolic compounds.

Automatic systems for on-line process control based on flow analyses were, already, developed and used in the monitorization of chemical species in wastewaters and industrial effluents. Flow injection analysis (FIA) has often been used as a technique to solve environmental analytical problems since its introduction by Ruzicka and Hansen in 1975 [7].

The demand for mechanically simple and robust flow injection methodology, as advanced by the needs of process analytical chemistry, associated to reliability, long-term stability and low frequency of maintenance required for process analysers, have been the driving force behind developing a sequential injection technique. While manual reconfiguration of the flow channel, high reagent consumption due to continuous flow operation, frequent assistance of peristaltic pumps and frequent recalibration of the system is acceptable in laboratory applications, these are obstructive in terms of cost and manpower in a process environment. The sequential injection analysis (SIA) conceived comprising only a single propeller system, single valve and a single channel allows to overcoming the difficulties related to the conventional flow systems. Minimising the number of mechanical components is beneficial for a process control environment as it increases the reliability of the apparatus [8-11].

This paper describes a SIA system for the simultaneous determination of nitrite, nitrate, sulphate and phenolic compounds in wastewaters. The nitrite determination is based on the Griess-Llosvay reaction: nitrite ion is diazotized with sulphanilamide [12] and the product of diazotization is coupled with N-(1-naphthyl)-ethylenediamine (N1NED) to form a coloured azo dye which is measured spectrophotometrically at $540 \mathrm{~nm}$. Nitrate is reduced on-line to nitrite in a copperized cadmium column and analysed as nitrite. The sulphate determination is based on the turbidimetric determination using barium chloride as reagent and the phenolic compounds determination (determination of the sum of compounds possessing a phenolic moiety) is based on the oxidative coupling with 4-AAP in alkaline solution, measuring the absorbances of the formed suspension and coloured compound, respectively, spectrophometrically at $540 \mathrm{~nm}$. 


\section{Original articles}

The parameters that affect those determinations were evaluated. The working characteristics of this system were shown to be rapid, sensitive, accurate and easily adapted to on-line process measurements of water chemical parameters.

\section{Experimental}

\section{Reagents and solutions}

Solutions were prepared using high purity water, with conductivity less than $0.1 \mu \mathrm{S} . \mathrm{cm}^{-1}$. Analytical grade reagents were used.

\section{Determination of nitrite and nitrate}

A nitrite stock solution $\left(1 \mathrm{~g} . \mathrm{dm}^{-3}\right)$ was prepared from $4.93 \mathrm{~g}$ of sodium nitrite $\left(\mathrm{NaNO}_{2}\right.$ from Riedel-deHaën, Germany), dried for $2 \mathrm{~h}$ at $105-110{ }^{\circ} \mathrm{C}$, in water. A nitrate stock solution $\left(1 \mathrm{~g} . \mathrm{dm}^{-3}\right)$ was prepared from $7.22 \mathrm{~g}$ of potassium nitrate $\left(\mathrm{KNO}_{3}\right.$ from Riedel-deHaën, Germany), dried for $2 \mathrm{~h}$ at $105-110^{\circ} \mathrm{C}$, in water. Working standards were daily prepared by appropriate dilution of each stock solution with water.

The chromogenic reagent (R1), for the Griess-Llosvay reaction, was prepared by dissolving $10 \mathrm{~g}$ of sulphanilamide $\left(\mathrm{C}_{6} \mathrm{H}_{8} \mathrm{~N}_{2} \mathrm{O}_{2} \mathrm{~S}\right.$ from Fluka, Switzerland) and $1 \mathrm{~g}$ of N1NED $\left(\mathrm{C}_{12} \mathrm{H}_{14} \mathrm{~N}_{2} 2 \mathrm{HCl}\right.$ from Sigma, Germany) in $100 \mathrm{~cm}^{3}$ of phosphoric acid $\left(\mathrm{H}_{3} \mathrm{PO}_{4} 85 \%\right.$ from Merck, Germany) and $800 \mathrm{~cm}^{3}$ of water. The reagent was stored in a brown glass in a refrigerator.

A carrier solution $(\mathrm{C} 1)$ was prepared by dissolving $0.4 \mathrm{~g}$ of EDTA $2 \mathrm{H}_{2} \mathrm{O} \quad\left(\mathrm{C}_{10} \mathrm{H}_{14} \mathrm{~N}_{2} \mathrm{Na}_{2} \mathrm{O}_{8} \cdot 2 \mathrm{H}_{2} \mathrm{O}\right.$ from Merck, Germany) and $70 \mathrm{~g}$ of ammonium chloride $\left(\mathrm{NH}_{4} \mathrm{Cl}\right.$ from Merck, Germany) in $1 \mathrm{dm}^{3}$ of water. The $\mathrm{pH}$ of this solution was adjusted to 9.0-9.5 with a few drops of ammonia solution $\left(\mathrm{NH}_{3}\right.$ from Riedel-deHaën, Germany).

Copperized cadmium column was prepared by adding $5 \mathrm{~g}$ of cadmium particles (Cd from Merck, Germany, diameter between 0.5 and $1 \mathrm{~mm}$ ) to $50 \mathrm{~cm}^{3}$ of a copper (II) sulphate solution ( $0.25 \mathrm{~g}$ of $\mathrm{CuSO}_{4}$ from Merck, Germany) and stirring for 2 minutes. The resulting copperized cadmium was washed with $2 \mathrm{M}$ hydrochloric acid ( $\mathrm{HCl}$ from RiedeldeHaën, Germany), two times with $50 \mathrm{~cm}^{3}$, and ammonium chloride $\left(\mathrm{NH}_{4} \mathrm{Cl}\right.$ from Merck, Germany) solution $\left(10 \mathrm{~g} . \mathrm{dm}^{-3}\right)$. The resulting particles were packed into Teflon tube with $7 \mathrm{~cm}$ of length and $1.5 \mathrm{~mm}$ of inner diameter.

\section{Determination of phenolic compounds}

Stock solution of phenolic compounds $\left(1 \mathrm{~g} . \mathrm{dm}^{-3}\right)$ was obtained by initial solution of accurately weighted solid substance $\left(\mathrm{C}_{6} \mathrm{H}_{6} \mathrm{O}\right.$ from Riedel-deHaën, Germany), in few millilitres of $0.1 \mathrm{M}$ sodium hydroxide $(\mathrm{NaOH}$ from RiedeldeHaën, Germany). Working standards were daily prepared by appropriated dilution, of the stock solution, with water.
A buffer solution comprised $5.2 \mathrm{~g} \mathrm{NaHCO}_{3}$ (Merck, Germany), $5.8 \mathrm{~g} \mathrm{H}_{3} \mathrm{BO}_{3}$ (Riedel-deHaën, Germany) and $6.2 \mathrm{~g} \mathrm{KOH}$ (Riedel-deHaën, Germany) per $\mathrm{dm}^{-3}$ of water. One of the reagents (R2) was prepared by dissolution of $1 \mathrm{~g}$ of 4-AAP (Sigma, Germany) in buffer. The $\mathrm{pH}$ of this reagent solution was accurately adjusted to $10.2 \pm 0.2$ by the addition of potassium hydroxide (KOH from Riedel-deHaën, Germany) or hydrochloric acid ( $\mathrm{HCl}$ from Riedel-deHaën, Germany). The oxidizing reagent (R3) was prepared by dissolution of $3 \mathrm{~g} \mathrm{~K}_{3}\left[\mathrm{Fe}(\mathrm{CN})_{6}\right]$ (Riedel-deHaën, Germany) in $1 \mathrm{dm}^{3}$ of water. The $\mathrm{pH}$ was adjusted to 11 with sodium hydroxide ( $\mathrm{NaOH}$ from Riedel-deHaën, Germany). Both reagent solutions had to be prepared at the beginning of each working day.

\section{Determination of sulphate}

A stock solution of sulphate $\left(1 \mathrm{~g} . \mathrm{dm}^{-3}\right)$ was prepared by dissolving $3.35 \mathrm{~g} \mathrm{Na}_{2} \mathrm{SO}_{4} 10 \mathrm{H}_{2} \mathrm{O}$ (Merck, Germany) in water. Working standards were daily prepared by appropriate dilution of the stock solution with water.

A buffer solution was prepared by dissolving $0.4 \mathrm{~g}$ of EDTA $2 \mathrm{H}_{2} \mathrm{O}$ and $70 \mathrm{~g}$ of ammonium chloride in $1 \mathrm{dm}^{3}$ of water (same solution used as carrier in the nitrite and nitrate determination).

A barium chloride reagent solution (R4) containing a potassium hydrogenphthalate-hydrochloric acid buffer at pH 2.5 was prepared by adding $388 \mathrm{~cm}^{3}$ of a $0.1 \mathrm{M}$ hydrochloric acid solution ( $\mathrm{HCl}$ from Riedel-deHaën, Germany) to $500 \mathrm{~cm}^{3}$ of a $0.1 \mathrm{M}$ potassium hydrogen phthalate solution $\left(\mathrm{C}_{8} \mathrm{H}_{5} \mathrm{KO}_{4}\right.$ from Riedel-deHaën, Germany). $10 \mathrm{~g}$ of $\mathrm{BaCl}_{2} 2 \mathrm{H}_{2} \mathrm{O}$ (Merck, Germany), $1 \mathrm{~g}$ of thymol (V.P., Portugal) and $0.62 \mathrm{~g}$ of gelatine (V.P., Portugal) were dissolved in this buffer and the solution diluted to $1 \mathrm{dm}^{3}$ with water. The reagent was filtered through a Millipore membrane (type HA) $(45 \mu \mathrm{m})$.

\section{Equipment}

The sequential injection system used was composed of individual components. A CRISON microBU 2031 (Crison instruments, Alella, Spain) with a $5 \mathrm{~mL}$ syringe was used as propeller system. The liquids were propelled or aspirated at a constant flow-rate between $0.1-3 \mathrm{~cm}^{3} \cdot \mathrm{min}^{-1}$.

Two multiposition selection valves VICI (Valco Instruments Co. Inc.) with eight inlets and one central outlet each other were used as injection systems.

The manifolds were built from PTFE tubing ( $0.8 \mathrm{~mm}$ i.d.) with Gilson connectors. The confluence used was Perspex made.

A JENWAY 6300 spectrophotometer, equipped with an $18 \mu \mathrm{L}$ flow-through cell of $1 \mathrm{~cm}$ path length was used for absorbance measurements at $540 \mathrm{~nm}$. The detector output was recorder on a Kipp \& Zonen recorder and signal evaluation was made by peak-height measurement. 
The data acquisition control unity consisted of a microcomputer, whose software (written in QuickBasic) was developed for the manifold control. The communication between the microcomputer and the burette was made by standard serial RS232C protocol, whereas digital TTL signals, using an Advantech model 818 interface card was used for the connection with the valve. The same interface card was used for data acquisition.

\section{Conventional procedure}

The quality of the results obtained by the SIA system, for nitrite, nitrate, sulphate and phenolic compounds determination, was assessed by comparison with those obtained by the respective reference methods. Therefore, the procedures suggested by the "Standard Methods for the Examination of Water and Wastewater" ("Colorimetric Method" for nitrite, "Ultraviolet Spectrophotometric Screening Method" for nitrate, "Turbidimetric Method" for sulphate and "Direct Photometric Method" for phenolic compounds) [14] were applied.

\section{Results and discussion}

The simple manifold used for the simultaneous nitrite, nitrate, sulphate and phenolic compounds determination by SIA is depicted in figure 1. The respective working parameters have been studied.

Once established the optimal conditions of operation, the analytical features of the system have been determined and the quality of the results assessed.

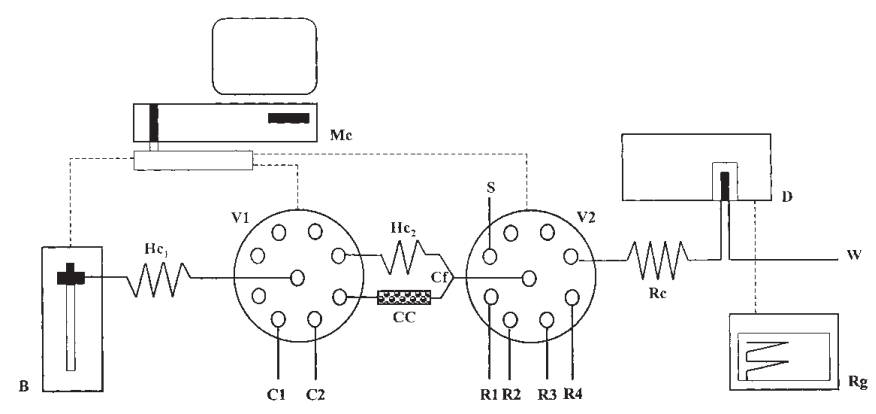

Figure 1. SIA manifold used in the simultaneous determination of nitrite, nitrate, sulphate and phenolic compounds in wastewaters of wood industry. S- sample; $\mathrm{C} 1-\mathrm{EDTA} / \mathrm{NH}_{4} \mathrm{Cl}$ solution; $\mathrm{C} 2$ - water; R1- Sulphanilamide/N1NED solution; R2- 4-AAP solution; R3 $\mathrm{K}_{3}\left[\mathrm{Fe}(\mathrm{CN})_{6}\right]$ solution; R4- Barium chloride solution; B- automatic burette; V1, V2- valves; D- detector; Rg- recorder; Mcmicrocomputer; $\mathrm{Cf}$ - confluence; $\mathrm{Hc}_{1} ; \mathrm{Hc}_{2}$ - holding coils; Rc- reaction coil $(100 \mathrm{~cm})$; CC- copper-cadmium column; W- waste.

\section{System optimization}

The analysis, for each chemical parameter, by the proposed system consists basically in the sequential aspiration of well defined reagent and sample zones which are adjacent to each other in a holding coil. After the valve has been moved to the detector position, the flow is reversed and the zones mutually disperse and merge in each other as they pass through a reaction coil towards the detector. For the simultaneous nitrite, nitrate, sulphate and phenolic compounds determination with the developed system (Fig. 1), a total measuring cycle comprised the four measuring cycles corresponding to the determination of nitrite and nitrate, determination of sulphate and determination of phenolic compounds, all four running continuously.

For the nitrate determination a measuring cycle was constituted by the following operations:

- aspiration of carrier (C1) and introduction in Rc;

- aspiration of the sample (S) and introduction in the copper-cadmium column (CC);

- aspiration of reagent (R1) to $\mathrm{Hc}_{2}$;

- finally, was making pass through Rc, to the detector, the following sequence: $\mathrm{R} 1 / \mathrm{S}$ from $\mathrm{CC} / \mathrm{R} 1$, followed by C1.

For nitrite:

- aspiration of carrier (C1) and introduction in Rc;

- aspiration of reagent (R1), sample (S) and reagent (R1) again and introduction in Rc, on the way to the detector, followed by $\mathrm{C} 1$.

For sulphate determination:

- aspiration of a little portion of carrier (C2), followed by a small volume of buffer solution (C1) and carrier (C2) again, to $\mathrm{Hc}_{1}$; to $\mathrm{Hc}_{1}$;

- aspiration of sample (S) and aspiration of reagent (R4)

- by reversing the flow, introduction on the pathway to the detector $(\mathrm{Rc})$ the sequence aspirated to $\mathrm{Hc}_{1}$, followed by carrier (C2).

Finally, for phenolic compounds determination:

- aspiration of carrier (C2) and introduction in Rc;

- aspiration of oxidizing reagent (R3), sample (S), 4-AAP (R2) and oxidizing reagent (R3) again, to $\mathrm{Hc}_{1}$;

- by reversing the flow, introduction on the pathway to the detector $(\mathrm{Rc})$ the sequence introduced on the $\mathrm{Hc}_{1}$ followed by carrier (C2).

In order to optimise the proposed SIA manifold, the influence of the hydrodynamic and chemical parameters on the magnitude of the peak height, reproducibility and accuracy of the results was investigated for each chemical species under study, individually. Experimental parameters were optimised by a univariate approach. 


\section{Original articles}

\section{Determination of nitrite and nitrate}

The concentrations of N1NED and sulphanilamide in phosphoric acid $(85 \%)$ that produce maximum analytical signals were evaluated to be 1 and $10 \mathrm{~g} \cdot \mathrm{dm}^{-3}$, respectively. The optimum ammonium chloride concentration, in the carrier stream, was $10 \mathrm{~g} . \mathrm{dm}^{-3}$; above this level, the response decreased because chloride ions inhibited the derivatization reaction and the reduction step, whereas below this level the response was erratic because of the decreased buffering capacity of the carrier stream.

The analytical signal was dependent on the changes of the length of the pathways to the detector. Lengths between 50 and $200 \mathrm{~cm}$ were tried, a decreasing in the analytical response being observed when longer pathways were used. A $100 \mathrm{~cm}$ pathway was chosen for further work.

Varying the flow rates, during the measurement step, over the range $0.5-3.0 \mathrm{~cm}^{3} \cdot \mathrm{min}^{-1}$ did not produce any significant changes in the analytical signals. In addition, the reduction of nitrate to nitrite was quantitative in the above range of flow rates. Hence, flow rate of $2 \mathrm{~cm}^{3} \cdot \mathrm{min}^{-1}$ was used, this being a compromise between the sampling rate and the height of the peak.

For nitrate determination, the volume of sample introduced in the copperized cadmium column has a significant effect on the analytical signal. Precise and accurate results were obtained when a $120 \mathrm{~mm}^{3}$ volume was used, because with this value the entire column was filled with sample and the dispersion was less. For nitrite determination the signal increased with increasing sample volume in the range 10$500 \mathrm{~mm}^{3} .80 \mathrm{~mm}^{3}$ of sample was chosen for further work.

Furthermore, it was observed that the increase of the peak height and sensitivity of the measurements was better achieved by intercalating the sample in equal volumes of reagent. Hence, in the nitrate case, sample was intercalated in $200+200 \mathrm{~mm}^{3}$ of reagent and, in the nitrite case, sample was intercalated in $100+100 \mathrm{~mm}^{3}$ of reagent.

The copperized cadmium column is the critical component of the manifold with regard to unattended operating lifetime. The effect of varying the length of the column shows that shorter columns give higher sensitivity because the sample is less dispersed, but longer columns obviously have a greater reducing capacity and therefore a longer lifetime. A $7 \mathrm{~cm}$ length and a $1.5 \mathrm{~mm}$ inner diameter column were used for all further experiments.

\section{Determination of sulphate}

The formation of the correct barium sulphate suspension in the tubes of the sequential injection system was of critical importance in the presence of the proposed process analyser. This was achieved by optimization of the composition of the barium chloride reagent solution. Using a solution of barium chloride in water the peaks obtained were small and the system was neither sensitive nor precise. It was observed that when the solution was acidified, the results improved with an increase in sensitivity. The barium chloride solution with a $\mathrm{pH}$ of 2.5 gave the greatest sensitivity. A barium chloride solution containing a potassium hydrogenphthalatehydrochloric acid buffer at $\mathrm{pH}=2.5$ was used [15]. The addition of thymol and gelatine improved both the sensitivity and the reproducibility and overcome the problem correlated with the overnight precipitation of potassium hydrogenphthalate. The reagent was filtered through a Millipore membrane (type HA) $(45 \mu \mathrm{m})$. This removed completely the small background value resulting from gelatine addition.

Lengths of pathways to the detector between 50 and $200 \mathrm{~cm}$ were tried. The best analytical responses were obtained with a $100 \mathrm{~cm}$ pathway and when $200 \mathrm{~mm}^{3}$ of sample were used.

Upon varying the flow rate, selected for the measurement step, from 0.1 to $3 \mathrm{~cm}^{3} \cdot \mathrm{min}^{-1}$ no significant change of the analytical response was observed. Due to the rapid reaction between sample and reagent, a flow rate of $3 \mathrm{~cm}^{3} \cdot \mathrm{min}^{-1}$ was used, this being a compromise between the sampling rate and the height of the peak.

One of the problems associated with the turbidimetric determination of sulphate, is the build up of barium sulphate precipitate in the tubes of the flow system, which tends to settle in the flow cell. This leads to low precision and ultimately blocks the manifold. To prevent this problem an alkaline buffer-EDTA solution was used. With this solution passing in the tubes of the system, there was no accumulation of precipitate in the tubes and in the flow cell. So, the proposed sequential injection analysis system, would need a sequence of zones like: water, alkaline buffer-EDTA solution, water, sample and reagent. The order in which the different sequences of carrier, buffer, sample and reagent are draw up and propelled into the detector is very important. The results obtained revealed that the alkaline buffer-EDTA solution had to be separated from the acidified barium chloride reagent solution by a water zone. Better results were obtained when the sample zone was placed between the water and the reagent.

\section{Determination of phenolic compounds}

Accordingly to previous reports $[14,16]$, the oxidative coupling reaction with 4-AAP was performed in alkaline buffer solution using $\mathrm{K}_{3}\left[\mathrm{Fe}(\mathrm{CN})_{6}\right]$ as oxidising agent. The $\mathrm{pH}$ of the buffer should be $10 \pm 0.2$, and its strength had to be high enough to maintain this value during the mixing of the sample with the reagents, hence granting low $\mathrm{pH}$ interferences. The $\mathrm{pH}$ of the $\mathrm{K}_{3}\left[\mathrm{Fe}(\mathrm{CN})_{6}\right]$ solution had to be 11 . The addition of 4-AAP to the sample for coupling reaction was performed prior to $\mathrm{K}_{3}\left[\mathrm{Fe}(\mathrm{CN})_{6}\right]$ addition to the oxidizing process. In this work, we chose to add sample to 4-AAP in first place and then intercalate the resulting product in equal volumes of oxidizing reagent, increasing, by this way, the analytical signal.

$\mathrm{K}_{2} \mathrm{~S}_{2} \mathrm{O}_{8}$ and $\mathrm{K}_{3}\left[\mathrm{Fe}(\mathrm{CN})_{6}\right]$ were studied as oxidizing agents. $\mathrm{K}_{2} \mathrm{~S}_{2} \mathrm{O}_{8}$ showed slow oxidation kinetics that can only be compensated by using a very high oxidant concentration. 
The optimal concentration of $\mathrm{K}_{3}\left[\mathrm{Fe}(\mathrm{CN})_{6}\right]$ was established and, therefore the baseline absorbance was low and stable. Using a high excess of oxidizing agent, to increase the reaction kinetics, some problems were observed namely Schlieren effect [17] when the mixing of the sample and the two reagents was incomplete. A noisy baseline was obtained even when a long pathway to the detector (up to $200 \mathrm{~cm}$ ) was used. Moreover, reaction of 4-AAP with excess of oxidizing agent could be observed in the absence of phenolic compounds causing a high blank value. Lower concentrations of oxidizing agent resulted in insufficient supply of reagent.

Optimization of the reagent composition was accomplished by varying the concentrations of 4-AAP and $\mathrm{K}_{3}\left[\mathrm{Fe}(\mathrm{CN})_{6}\right]$ and it was found that $1 \mathrm{~g} \cdot \mathrm{dm}^{-3}$ 4-AAP was enough to promote the maximum response whereas the concentration of $\mathrm{K}_{3}\left[\mathrm{Fe}(\mathrm{CN})_{6}\right]$ should be in the range of $1-3 \mathrm{~g} \cdot \mathrm{dm}^{-3}$.

A flow rate of $2.0 \mathrm{~cm}^{3} \cdot \mathrm{min}^{-1}$ was selected for the measurement step, after having studied other flow rates. Under these conditions, a maximum response and a high sampling rate were attained.

Using this manifold the sample volume required to almost achieve the steady-state signal was $200 \mathrm{~mm}^{3}$. With a $100 \mathrm{~mm}^{3}$ volume more than $90 \%$ of this value was reached.

\section{Analytical figures of merit}

In figure 2, analytical signals obtained for the different standards of nitrite, nitrate, sulphate and phenolic compounds, with concentrations between 0.05 and $25 \mathrm{mg} . \mathrm{dm}^{-3}, 0.05$ and $25 \mathrm{mg} \cdot \mathrm{dm}^{-3}, 5$ and $200 \mathrm{mg} \cdot \mathrm{dm}^{-3}, 0.5$ and $50 \mathrm{mg} \cdot \mathrm{dm}^{-3}$, respectively, were presented.
The RSD (relative standard deviation) and DL (detection limit) values obtained for the different analytes as well as the linear calibration ranges and regression equations are given in table I.

In nitrite and nitrate determination the detection limits are slightly smaller than those obtained using a FIA (flow injection analysis $)$ manifold $\left(0.1 \mathrm{mg} \cdot \mathrm{dm}^{-3}\right.$ for nitrite and $0.5 \mathrm{mg} \cdot \mathrm{dm}^{-3}$ for nitrate) but in the other side, the linear range is larger for nitrite $\left(0-10 \mathrm{mg} \cdot \mathrm{dm}^{-3}\right)$ and smaller for nitrate $\left(0-35 \mathrm{mg} \cdot \mathrm{dm}^{-3}\right)$ [18]. Better limit of detection was obtained for sulphate with this method compared with that obtained with a FIA system $\left(19 \mathrm{mg} \cdot \mathrm{dm}^{-3}\right)$ based on the formation of $\mathrm{FeSO}_{4}{ }^{+}$complex cation, but, in other hand, the linear range is smaller $\left(25-600 \mathrm{mg} \cdot \mathrm{dm}^{-3}\right)$ [19]. In the phenolic compounds determination using this method we obtained slightly larger detection limits $\left(0.03 \mathrm{mg} \cdot \mathrm{dm}^{-3}\right)$ than those obtained using a FIA system and linear range are similar when compared with the spectrophotometric and amperometric FIA systems [20,21].

To evaluate and compare the sampling rate of this system with others different methodologies we had to take in consideration that this system was applied to multiparametric determination. FIA systems applied for each individual determination gave higher sampling rates but with the proposed system, at a sampling rate about 12 samples. $\mathrm{h}^{-1}$ we obtain information about four different chemical species.

\section{Application to samples analysis}

The quality of the results obtained by the automatic system developed for the simultaneous determination of nitrite, nitrate, sulphate and phenolic compounds in wastewaters

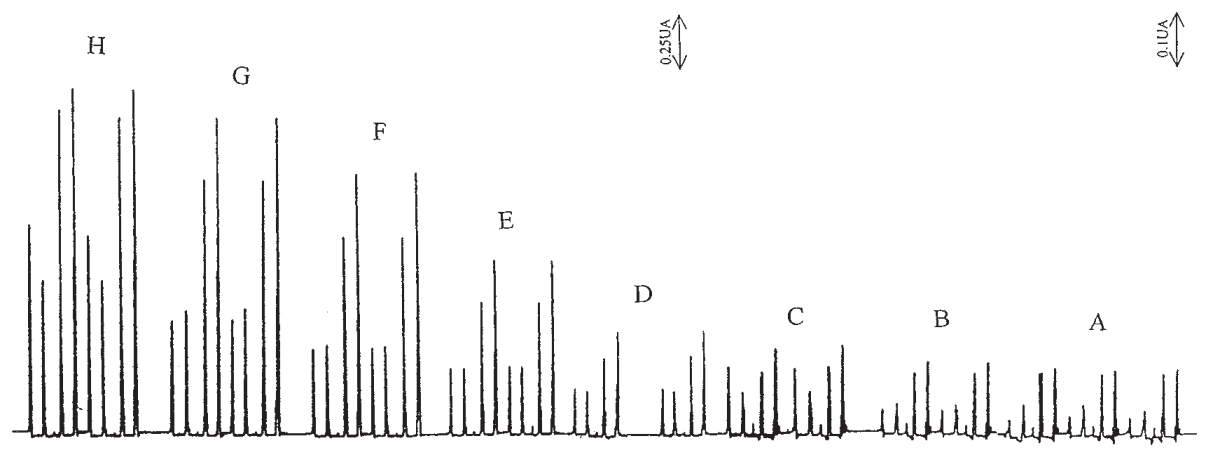

Figure 2. Calibration record obtained for the different standards (two measurements of the content of each standard).

\begin{tabular}{lcccccccc} 
& A & B & C & D & E & F & G & H \\
\hline Nitrite $\left(\mathrm{mg} \cdot \mathrm{dm}^{-3}\right)$ & 0.05 & 0.5 & 1 & 5 & 10 & 15 & 20 & 25 \\
Nitrate $\left(\mathrm{mg} \cdot \mathrm{dm}^{-3}\right)$ & 0.05 & 0.5 & 1 & 5 & 10 & 15 & 20 & 25 \\
Sulphate $\left(\mathrm{mg}^{-3} \mathrm{dm}^{-3}\right)$ & 5 & 10 & 20 & 50 & 75 & 100 & 150 & 200 \\
Phenol $\left(\mathrm{mg} \cdot \mathrm{dm}^{-3}\right)$ & 0.5 & 1 & 5 & 10 & 15 & 20 & 25 & 50 \\
\hline
\end{tabular}




\section{Original articles}

Table I. Figures of merit of the sequential injection method.

\begin{tabular}{|c|c|c|c|c|c|}
\hline Analyte & $\begin{array}{c}\text { Linear calibration } \\
\text { Equation } \\
y=\text { absorbance } \\
x=\text { concentration } \\
\left(\mathrm{mg}^{\left.-\mathrm{dm}^{-3}\right)}\right.\end{array}$ & $\begin{array}{c}\text { Correlation } \\
\text { coefficient } \\
(n=8)\end{array}$ & $\begin{array}{l}\text { Linear range } \\
\left(\mathrm{mg} \cdot \mathrm{dm}^{-3}\right)\end{array}$ & $\begin{array}{c}D L \\
(3 \sigma) \\
\left(\mathrm{mg} \cdot \mathrm{dm}^{-3}\right)\end{array}$ & $\begin{array}{c}R S D \\
(\%) \\
(n=10)\end{array}$ \\
\hline Nitrite & $Y=0.275 x+0.469$ & 0.9994 & $0.05-25$ & 0.01 & 2 \\
\hline Nitrate & $\mathrm{Y}=0.097 x+0.043$ & 0.9995 & $0.05-15$ & 0.01 & 0.6 \\
\hline Sulphate & $Y=0.018 x+0.197$ & 0.9996 & $5-200$ & 1 & 1.5 \\
\hline Phenolic Compounds & $Y=0.098 x+0.145$ & 0.9998 & $0.5-25$ & 0.1 & 2.1 \\
\hline
\end{tabular}

was evaluated by comparing the results with those obtained by the respective reference methods.

With the purpose of evaluating the accuracy of the proposed methodology, a correlation between the values obtained from the SIA method (Cf) and those given by the respective reference method $(\mathrm{Cr})$, for each analyte, was established in 10 samples of wastewaters collected at wood industry. These samples correspond to the influents and effluents of the wastewater treatment plant. By establishing a linear regression $(\mathrm{Cf}=\mathrm{Co}+\mathrm{SCr})$ between the results obtained by the different methodologies, that was observed relative small intercept values $(0.060$ for nitrite, 1.006 for nitrate, 0.1497 for sulphate and 0.1106 for phenolic compounds), slopes near unity ( 0.9978 for nitrite, 0.9985 for nitrate, 0.9655 for sulphate and 0.9633 for phenolic compounds) and correlation coefficients close to one (0.9982 for nitrite, 0.9997 for nitrate, 0.9984 for sulphate and 0.9988 for phenolic compounds) showing a good agreement between the different methodologies.

Tables II-V present the results obtained using the developed system and the respective reference methods, for the 10 wastewater samples.

Table II. Results obtained, for 10 wastewater samples, in the determination of nitrite.

\begin{tabular}{lcr}
\hline $\begin{array}{l}S^{a} A^{a} \\
\left(m g . d m^{-3}\right)\end{array}$ & $\begin{array}{c}\text { Reference Method } \\
\left(m g . d m^{-3}\right)\end{array}$ & $\begin{array}{c}R S D^{b} \\
(\%)\end{array}$ \\
\hline $0.8( \pm 0.008)$ & 0.84 & -4.7 \\
$0.5( \pm 0.069)$ & 0.52 & -4.7 \\
$233( \pm 0.115)$ & 228 & 2.1 \\
$256( \pm 0.058)$ & 259 & -1.1 \\
$0.5( \pm 0.030)$ & 0.51 & -1.9 \\
$255( \pm 0.104)$ & 245 & 4.0 \\
$290( \pm 0.050)$ & 296 & -2.0 \\
$221( \pm 0.076)$ & 220 & 0.4 \\
$194( \pm 0.040)$ & 200 & 3.0 \\
$206( \pm 0.126)$ & 210 & -1.9
\end{tabular}

a mean and absolute standard deviation $\left(\mathrm{mg}^{\mathrm{d}} \mathrm{dm}^{-3}\right)$ for each sample.

b Relative Standard Deviation (RSD) between the results attained by the two methodologies.

\section{Conclusion}

A sequential injection analysis system, with a spectrophotometric detector, was developed to evaluate, simultaneously,

Table III. Results obtained, for 10 wastewater samples, in the determination of nitrate.

\begin{tabular}{lcr}
\hline $\begin{array}{l}\text { SIA }^{a} \\
\left(\mathrm{mg} . \mathrm{dm}^{-3}\right)\end{array}$ & $\begin{array}{c}\text { Reference Method } \\
\left(\mathrm{mg} . \mathrm{dm}^{-3}\right)\end{array}$ & $\begin{array}{c}\text { RSD }^{b} \\
(\%)\end{array}$ \\
\hline $1.2( \pm 0.029)$ & 1.27 & -5.5 \\
$1.6( \pm 0.029)$ & 1.64 & -2.4 \\
$570( \pm 0.058)$ & 575 & -0.8 \\
$74( \pm 0.028)$ & 71 & 4.2 \\
$1( \pm 0.025)$ & 11 & -9.0 \\
$47( \pm 0.029)$ & 46 & 2.1 \\
$482( \pm 0.125)$ & 476 & 1.2 \\
$124( \pm 0.025)$ & 120 & 3.3 \\
$104( \pm 0.076)$ & 109 & -4.5 \\
$114( \pm 0.104)$ & 110 & 3.6 \\
\hline
\end{tabular}

a mean and absolute standard deviation $\left(\mathrm{mg} \cdot \mathrm{dm}^{-3}\right)$ for each sample.

b Relative Standard Deviation (RSD) between the results attained by the two methodologies.

Table IV. Results obtained, for 10 wastewater samples, in the determination of sulphate.

\begin{tabular}{lcc}
\hline $\begin{array}{l}\text { SIA }^{a} \\
\left(\mathrm{mg} . \mathrm{dm}^{-3}\right)\end{array}$ & $\begin{array}{c}\text { Reference Method } \\
\left(\mathrm{mg} . \mathrm{dm}^{-3}\right)\end{array}$ & $\begin{array}{c}R S D^{b} \\
(\%)\end{array}$ \\
\hline $48.5( \pm 0.025)$ & 49 & -1 \\
$37.5( \pm 0.036)$ & 36.2 & 3.5 \\
$166( \pm 0.029)$ & 162 & 2.4 \\
$500( \pm 0.086)$ & 522 & -4.2 \\
$26.5( \pm 0.057)$ & 26.3 & 0.7 \\
$250( \pm 0.104)$ & 248 & 0.8 \\
$312( \pm 0.035)$ & 308 & 1.3 \\
$222( \pm 0.029)$ & 220 & 0.9 \\
$276( \pm 0.046)$ & 281 & -1.7 \\
$222( \pm 0.029)$ & 218 & 1.8 \\
\hline
\end{tabular}

${ }^{a}$ mean and absolute standard deviation $\left(\mathrm{mg}^{\mathrm{d}} \mathrm{dm}^{-3}\right)$ for each sample.

${ }^{b}$ Relative Standard Deviation (RSD) between the results attained by the two methodologies. 
Table V. Results obtained, for 10 wastewater samples, in the determination of phenolic compounds.

\begin{tabular}{lcc}
\hline $\begin{array}{l}\text { SIA }^{a} \\
\left(\mathrm{mg}^{\mathrm{d}} \mathrm{dm}^{-3}\right)\end{array}$ & $\begin{array}{c}\text { Reference Method } \\
\left(\mathrm{mg} . \mathrm{dm}^{-3}\right)\end{array}$ & $\begin{array}{c}R S D^{b} \\
(\%)\end{array}$ \\
\hline $23.9( \pm 0.058)$ & 25 & -4.4 \\
$23.5( \pm 0.058)$ & 24.5 & -4 \\
$21( \pm 0.032)$ & 22 & -4.5 \\
$32( \pm 0.058)$ & 33 & -3 \\
$22.3( \pm 0.087)$ & 22.7 & -1.7 \\
$16( \pm 0.058)$ & 16.8 & -4.7 \\
$16( \pm 0.029)$ & 16.4 & 2.4 \\
$11( \pm 0.025)$ & 11.1 & -0.9 \\
$29.3( \pm 0.029)$ & 30 & -2.3 \\
$11.1( \pm 0.029)$ & 11.3 & -1.8 \\
\hline
\end{tabular}

${ }^{a}$ mean and absolute standard deviation $\left(\mathrm{mg} \cdot \mathrm{dm}^{-3}\right)$ for each sample.

${ }^{\mathrm{b}}$ Relative Standard Deviation (RSD) between the results attained by the two methodologies.

nitrite, nitrate, sulphate and phenolic compounds concentrations in wastewaters.

Some aspects are clearly advantageous, like the use of small volumes of reagents and sample, what is important in continuous analysis as it means less maintenance and less waste disposal. Additionally, all components and solutions are clustered around the two selection valves, thus facilitating the future minimization of the system and its total automatization, which means computer-controlled operations running for extended periods. The greatest advantage of the system is probably the fact that the same manifold configuration can accommodate a variety of chemistries, without requiring physical reconfiguration. It was observed that the developed system allowed the simultaneous determination of four important water chemical parameters without need of changing the system apparatus.

Nevertheless, there are two drawbacks that must be mentioned. First, since the aspiration of the wash and sequencing of the zones in reaction coil takes some time, the sampling frequency of this system is presently lower than that of conventional FIA systems, in which the filling of the injection valve is a matter of a few seconds. Secondly, this system requires special software, as the sequencing and injection are entirely computer driven. This, however, is not an obstacle to using this technique. Its attributes are valuable for continuous monitoring and process control and overcome its drawbacks in a practical and readily accessible form in wastewaters analysis.

The application of the developed system to nitrite, nitrate, phenolic compounds and sulphate simultaneous determination shows that it is an inexpensive and rapid technique, yielding results in good agreement with those provided by reference methodologies, with a high sensitivity, accuracy and relative standard deviations less than $2.0 \%$, $0.7 \%, 1.5 \%$ and $2.2 \%$ for nitrite, nitrate, sulphate and phenolic compounds, respectively.

\section{Acknowledgements}

The authors thank the financial support through the ECAMOCO-FAIR-CT96-1198 project. One of us (I.V.O.S. Pinto) thanks PRAXIS XXI program for the $\mathrm{PhD}$ grant (BD/9539/96).

\section{References}

1. Ivanov, M.V.; Freney, J.R. (Eds) The Global Biogeochemical Sulphur Cycle, SCOPE, 1983.

2. Foster, S.S.D.; Bridge, L.R.; Geake, A.K.; Lawrence, A.R.; Parker, J.M. The Groundwater Nitrate Problem: A summary of research on the impact of agricultural land-use practices on ground-water quality between 1976 and 1985, (Hydrogeol. Rep. Br. Geol. Survey), 1986, No.86/2.

3. Casey, H.; Clarke, R.T. Freshwater biol. 1979, 9, 91.

4. Hoather, R.C.; Rackham, R.F. Analyst 1959, 84, 548.

5. Sax, N.I. Dangerous Properties of Industrial Materials; New York: Reinhold, 1993, $2^{\text {nd }}$ Ed.

6. Diário da República, I série-A, Anexo XVIII 1998, nº 176.

7. Ruzicka, J.; Hansen, E.H. Anal. Chim. Acta 1975, 78, 145.

8. Ruzicka, J.; Gubeli, T. Anal. Chem. 1991, 63, 1680.

9. Ruzicka, J. Anal. Chim. Acta 1992, 261, 3.

10. Christian, G.D.; Ruzicka, J. Anal. Chim. Acta 1992, 261, 11.

11. Ruzicka, J. Analyst 1994, 119, 1925.

12. Van Staden, J.F. Anal. Chim. Acta 1982, 138, 403.

13. Giné M.F.; Bergamim, F. H.; Zagatto, E.A.; Reis, B.F. Anal. Chim. Acta 1980, 114, 191.

14. Standard Methods for the Examination of Water and Wastewater; Washington D.C.: American Public Health Association, 1985, 16 $6^{\text {th }}$ Ed, Part 510.

15. Van Staden, J.F.; Taljaard, R.E. Anal. Chim. Acta 1996, 331, 271.

16. Mohler, E.F.; Jacob, L.N. Anal. Chem. 1957, 29, 1369.

17. Fábio, R.P.R.; Joaquim, A.N. Química Nova 1996, 19(6), 636.

18. Kjolo, A.; Gorodkiewicz, E. Anal. Chim. Acta 1995, 302, 283.

19. Kjolo, A.; Michalowski, J.; Trojanowicz, M. Anal. Chim. Acta 1990, 228, 287.

20. Frenzel, W.; Oleksy-Frenzel, J.; Möller, J. Anal. Chim. Acta 1992, 261, 253.

21. Christophersen, M.J.; Cardwell, T.J. Anal. Chim. Acta 1996, $323,39$. 